\title{
Synthesis of new heteroaryldi(diindolyl)methanes: Colorimetric detection of DNA by di(diindolylmethyl)carbazoles
}

\author{
RAMU MEESALA and RAJAGOPAL NAGARAJAN* \\ School of Chemistry, University of Hyderabad, Central University (PO), Hyderabad 500046 \\ e-mail: rnsc@uohyd.ernet.in
}

MS received 16 October 2008; revised 29 January 2009

\begin{abstract}
We have synthesized di(diindolylmethyl)carbazoles and di(diindolylmethyl)pyrroles by the reaction of substituted indoles with the corresponding carbazole and pyrroledicarboxaldehydes by employing a new catalyst $\mathrm{PPh}_{3} \cdot \mathrm{CF}_{3} \mathrm{SO}_{3} \mathrm{H}$. We have also demonstrated the utility of di(diindolylmethyl) carbazole derivatives for the colourimetric and fluorometric detection of DNA.
\end{abstract}

Keywords. Di(diindolylmethyl)carbazoles; di(diindolylmethyl)pyrroles, triindolylmethane; UV-Vis titrations; fluorometric titrations.

\section{Introduction}

Biosensor technologies that focus on the direct detection of nucleic acids are currently an area of interest as they play a major role in clinical, forensic, and pharmaceutical applications. ${ }^{1,2}$ The molecular probes that cause an increase in both absorbance and emission intensity by association with the host biomacromolecules (e.g. DNA, RNA, and proteins) are very useful photoluminescent markers in genomics and proteomics. ${ }^{3}$ These simple and straightforward spectroscopic methods are especially advantageous because small organic dyes absorb and emit at wavelengths that do not interfere with the absorption of the DNA bases $\left(\lambda_{\max } \sim 260 \mathrm{~nm}\right)$. Indeed, spectrophotometric and spectrofluorimetric titrations are direct methodologies that indicate the association of a specific dye with DNA. ${ }^{4}$ The design of new small molecular organic fluorophores is not a simple task. ${ }^{5}$

Carbazole $^{6}$, indole $^{7}$ and pyrrole ${ }^{8}$ fragments are featured widely in a variety of pharmacologically and biologically active compounds. Bis(indolyl) alkanes and their derivatives constitute an important group of bioactive metabolites of terrestrial and marine origin $^{9}$ and hence there is a great deal of synthetic interest of these compounds. Although the extensive work have done on the simple alkyl and aryl diindolylmethanes ${ }^{10}$, the reports on the synthesis of heteroaryl diindolylmethanes are very rare. In particular

*For correspondence there were no reports on the synthesis of pyrrole diindolylmethanes to the best of our knowledge. Earlier attempt to the synthesis of diindolyl(pyrrolyl) methane by the reaction of pyrrole-2-carboxaldehyde with indole in presence of M.K-10 clay catalyst leads to triindolylmethane instead of diindolylmethane. ${ }^{11}$

\section{Experimental}

\subsection{Materials and reagents}

All the products obtained were purified by column chromatography using neutral silica gel (100-200 mesh). Hexane was used as a co-eluent. ${ }^{1} \mathrm{H},{ }^{13} \mathrm{C}$ and ${ }^{31} \mathrm{P}$ NMR were recorded in $400 \mathrm{MHz}$ spectrometer. The chemical shifts are reported in ppm downfield to TMS $(\delta=0)$ for ${ }^{1} \mathrm{H}$ NMR and relative to the central DMSO resonance ( $\delta=40 \cdot 15 \mathrm{ppm}$ ) for ${ }^{13} \mathrm{C}$ NMR. Mass spectral data was obtained from LC-MS. IR spectra were recorded on a FT-IR spectrometer using $\mathrm{KBr}$ pellets. Elemental analysis was carried out in $\mathrm{CHN}$ analyzer. Melting points are uncorrected. CT-DNA was purchased from Aldrich and it was sonicated to dissolve completely in $5 \mathrm{mM}$ Tris, $50 \mathrm{mM} \mathrm{NaCl}$, $\mathrm{pH}=7 \cdot 1$. Di(diindolylmehyl)carbazoles were dissolved in DMSO and used for DNA binding studies.

\subsection{Typical procedure for the preparation of $3 a$}

A mixture of 9-methyl-3,6-carbazoledicarboxaldehyde $(0.25 \mathrm{~g}, 1.0 \mathrm{mmol})$, indole $(0.48 \mathrm{~g}, 4.10 \mathrm{mmol})$ and 


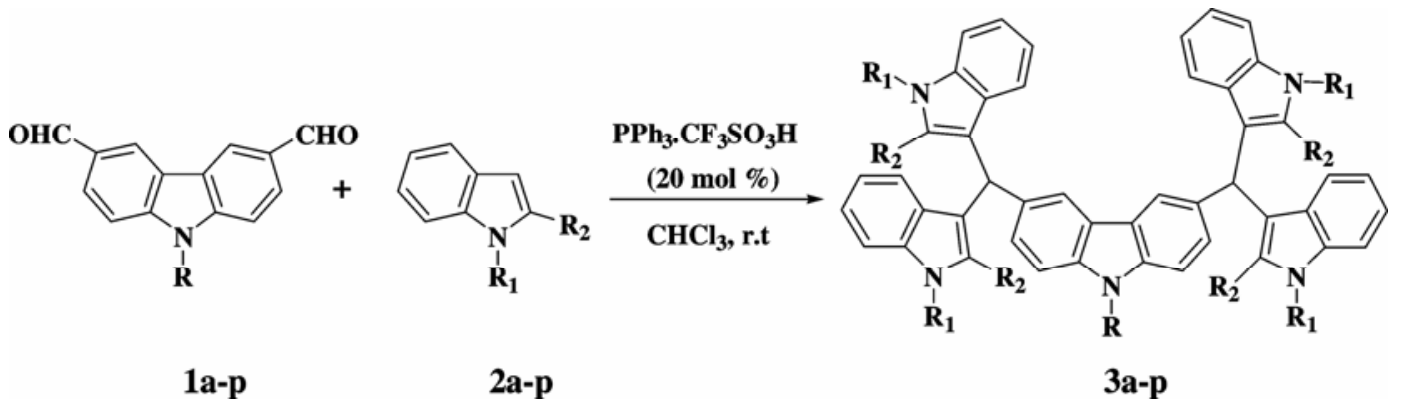

Scheme 1. Synthesis of di(diindolylmethyl)carbazoles.

Table 1. Synthesis of di(diindolylmethyl)carbazoles.

\begin{tabular}{llllccc}
\hline Entry & \multicolumn{1}{c}{$\mathrm{R}$} & $\mathrm{R}_{1}$ & $\mathrm{R}_{2}$ & Product & Time (h) & Yield (\%) $^{\mathrm{a}}$ \\
\hline $\mathrm{a}$ & $\mathrm{CH}_{3}$ & $\mathrm{H}$ & $\mathrm{H}$ & $\mathbf{3 a}$ & 1 & 75 \\
$\mathrm{~b}$ & $\mathrm{C}_{2} \mathrm{H}_{5}$ & $\mathrm{H}$ & $\mathrm{H}$ & $\mathbf{3 b}$ & 1 & 71 \\
$\mathrm{c}$ & $n-\mathrm{C}_{4} \mathrm{H}_{9}$ & $\mathrm{H}$ & $\mathrm{H}$ & $\mathbf{3 c}$ & 1 & 77 \\
$\mathrm{~d}$ & $\mathrm{CH}_{2} \mathrm{Ph}$ & $\mathrm{H}$ & $\mathrm{H}$ & $\mathbf{3 d}$ & 1 & 70 \\
$\mathrm{e}$ & $\mathrm{CH}_{3}$ & $\mathrm{CH}_{3}$ & $\mathrm{H}$ & $\mathbf{3 e}$ & 1 & 78 \\
$\mathrm{f}$ & $\mathrm{C}_{2} \mathrm{H}_{5}$ & $\mathrm{CH}_{3}$ & $\mathrm{H}$ & $\mathbf{3 f}$ & 1 & 80 \\
$\mathrm{~g}$ & $n-\mathrm{C}_{4} \mathrm{H}_{9}$ & $\mathrm{CH}_{3}$ & $\mathrm{H}$ & $\mathbf{3 g}$ & 1 & 81 \\
$\mathrm{~h}$ & $\mathrm{CH}_{2} \mathrm{Ph}$ & $\mathrm{CH}$ & $\mathrm{H}$ & $\mathbf{3 h}$ & 1 & 79 \\
$\mathrm{i}$ & $\mathrm{CH}_{3}$ & $\mathrm{H}$ & $\mathrm{CH}_{3}$ & $\mathbf{3 i}$ & 3 & 76 \\
$\mathrm{j}$ & $\mathrm{C}_{2} \mathrm{H}_{5}$ & $\mathrm{H}$ & $\mathrm{CH}_{3}$ & $\mathbf{3 j}$ & 3 & 71 \\
$\mathrm{k}$ & $n-\mathrm{C}_{4} \mathrm{H}_{9}$ & $\mathrm{H}$ & $\mathrm{CH}$ & $\mathbf{3 k}$ & 3 & 73 \\
1 & $\mathrm{CH}_{3} \mathrm{Ph}$ & $\mathrm{H}$ & $\mathrm{CH}$ & $\mathbf{3 1}$ & 3 & 69 \\
$\mathrm{~m}$ & $\mathrm{CH}_{3}$ & $\mathrm{H}$ & $\mathrm{Ph}$ & $\mathbf{3 m}$ & 12 & 64 \\
$\mathrm{n}$ & $\mathrm{C}_{2} \mathrm{H}_{5}$ & $\mathrm{H}$ & $\mathrm{Ph}$ & $\mathbf{3 n}$ & 12 & 61 \\
$\mathrm{o}$ & $n-\mathrm{C}_{4} \mathrm{H}_{9}$ & $\mathrm{H}$ & $\mathrm{Ph}$ & $\mathbf{3 o}$ & 12 & 60 \\
p & $\mathrm{CH}_{2} \mathrm{Ph}$ & $\mathrm{H}$ & $\mathrm{Ph}$ & $\mathbf{3 p}$ & 12 & 62 \\
\hline
\end{tabular}

${ }^{a}$ Yields are reported after column purification of the compounds

TPP triflate $(20 \mathrm{~mol} \%)$ in chloroform $(15 \mathrm{~mL})$ was stirred at room temperature for one hour. After completion of the reaction (TLC), the solvent was evaporated under reduced pressure and the crude material was subjected to column chromatography (hexane: ethyl acetate $=85: 15$ ) to afford the pure product in $75 \%$ yield. m.p. $115-116^{\circ} \mathrm{C}$; IR $(\mathrm{KBr})$ : $3404,3043,1607,1485,1413,1228,1083,1158$, $845,790,787,683 \mathrm{~cm}^{-1}$; ${ }^{1} \mathrm{H}$ NMR $(400 \mathrm{MHz}, \mathrm{TMS}$, DMSO- $\left.d_{6}\right) \delta: 3.64\left(3 \mathrm{H}, s, \mathrm{CH}_{3}\right), 5.97(2 \mathrm{H}, s), 6.78-$ $6.92(8 \mathrm{H}, m), 6.99-7.05(4 \mathrm{H}, m), 7.27-7.34(8 \mathrm{H}, m)$ $7.48(4 \mathrm{H}, s), 8.06(2 \mathrm{H}, s), 10.56(4 \mathrm{H}, s, \mathrm{NH}) ;{ }^{13} \mathrm{C}$ NMR $\left(100 \mathrm{MHz}, \mathrm{TMS}, \mathrm{DMSO}-d_{6}\right) \quad \delta: 37.5,65.4$ (aliphatic C), 108.9, 111.9, 118.7, 119.5, 119.8, $121 \cdot 3,122 \cdot 7,124 \cdot 3,126 \cdot 8,127 \cdot 3,128 \cdot 6,135 \cdot 7$, 137.2, 138.9 (aromatic C); LC-MS: $m / z=668$ $\left(\mathrm{M}-\mathrm{H}^{+}\right)$, negative mode; Anal. Calcd. for $\mathrm{C}_{47} \mathrm{H}_{35} \mathrm{~N}_{5}$; C, $84.28 ; \mathrm{H}, 5 \cdot 27 ; \mathrm{N}, 10.46 \%$ found: $\mathrm{C}, 84.41 ; \mathrm{H}$, $5 \cdot 35 ; \mathrm{N}, 10 \cdot 22 \%$.

\section{Results and discussion}

We report here the synthesis of di(diindolylmethyl)carbazole and pyrrole derivatives catalysed by a new catalyst $\mathrm{PPh}_{3} \cdot \mathrm{CF}_{3} \mathrm{SO}_{3} \mathrm{H} \quad(20 \mathrm{~mol} \%)$. Di(diindolylmethyl)carbazoles 3a-3p were synthesized in good yields by the reaction of 9alkylcarbazole-3,6-dicarboxaldehydes $\mathbf{1 a - 1 p}$ with various indole derivatives in the presence of a catalytic amount (20 mol\%) of $\mathrm{PPh}_{3} \cdot \mathrm{CF}_{3} \mathrm{SO}_{3} \mathrm{H}$ in $\mathrm{CHCl}_{3}$ at room temperature (scheme 1). The results are summarized in table 1, clearly indicating the scope and generality of the reaction. The more reaction time was observed in the case of 2-phenylindole derivatives. This may be due to the steric hindrance and the electron withdrawing nature of the phenyl ring which renders the nucleophilicity of the indole.

As shown in scheme 2, di(diindolylmethyl)pyrrole derivatives were formed by treating with 3,5- 


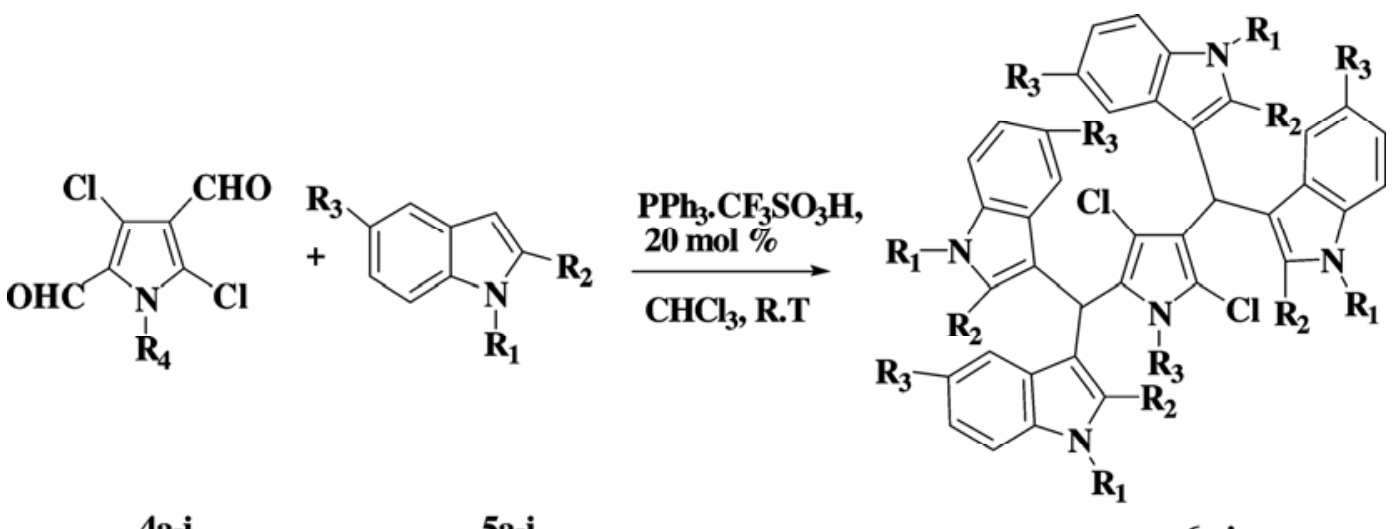

4a-i

5a-i

6a-i

Scheme 2. Synthesis of di(diindolylmethyl)pyrroles.

Table 2. Synthesis of di(diindolylmethyl)pyrroles.

\begin{tabular}{|c|c|c|c|c|c|c|c|}
\hline Entry & $\mathrm{R}_{1}$ & $\mathrm{R}_{2}$ & $\mathrm{R}_{3}$ & $\mathrm{R}_{4}$ & Product & Time & Yield (\%) \\
\hline a & $\mathrm{H}$ & $\mathrm{H}$ & $\mathrm{H}$ & $\mathrm{H}$ & $6 a$ & 2 & 74 \\
\hline $\mathrm{b}$ & $\mathrm{CH}_{3}$ & $\mathrm{H}$ & $\mathrm{H}$ & $\mathrm{H}$ & $6 b$ & 2 & 72 \\
\hline c & $\mathrm{H}$ & $\mathrm{CH}_{3}$ & $\mathrm{H}$ & $\mathrm{H}$ & $6 c$ & 3 & 70 \\
\hline $\mathrm{d}$ & $\mathrm{H}$ & $\mathrm{Ph}$ & $\mathrm{H}$ & $\mathrm{H}$ & $6 d$ & 12 & 59 \\
\hline $\mathrm{e}$ & $\mathrm{H}$ & $\mathrm{Ph}$ & $\mathrm{H}$ & $\mathrm{CH}_{3}$ & $6 e$ & 12 & 56 \\
\hline $\mathrm{f}$ & $\mathrm{H}$ & $(4-\mathrm{Br}) \mathrm{Ph}$ & $\mathrm{H}$ & $\mathrm{H}$ & $6 f$ & 12 & 61 \\
\hline $\mathrm{g}$ & $\mathrm{H}$ & $(4-\mathrm{OMe}) \mathrm{Ph}$ & $\mathrm{H}$ & $\mathrm{H}$ & $6 \mathrm{~g}$ & 12 & 58 \\
\hline $\mathrm{h}$ & $\mathrm{CH}_{2} \mathrm{Ph}$ & $\mathrm{H}$ & $\mathrm{H}$ & $\mathrm{H}$ & $6 \mathrm{~h}$ & 2 & 59 \\
\hline $\mathrm{i}$ & $\mathrm{H}$ & $\mathrm{H}$ & $\mathrm{Br}$ & $\mathrm{H}$ & $6 i$ & 2 & 63 \\
\hline
\end{tabular}

${ }^{b}$ Yields are reported after column purification of the compounds

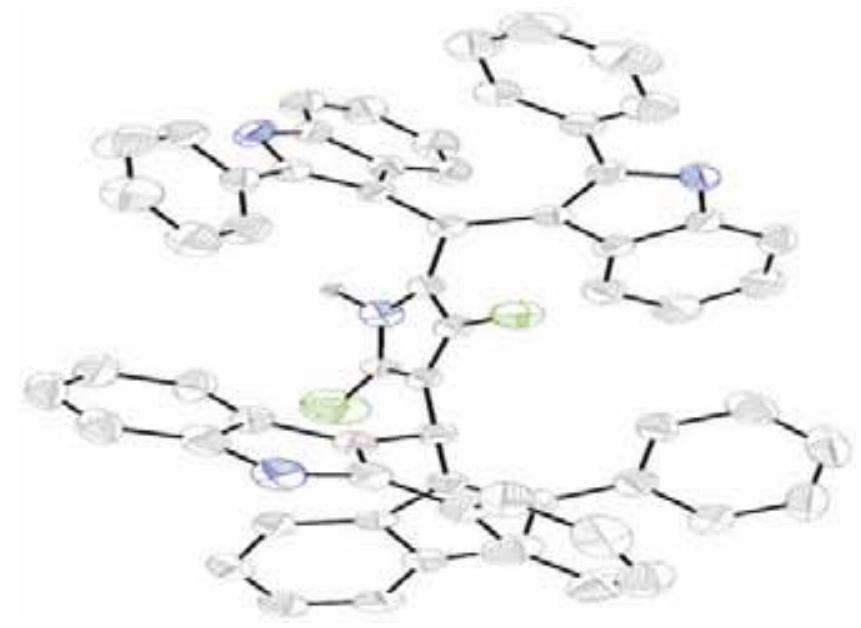

Figure 1. ORTEP diagram of 6e. Hydrogen atoms are omitted for clarity.

dichloro-2,4-pyrroledicarboxaldehyde with various indole derivatives. The results are summarized in table 2 . The formation of triindolylmethane $(\sim 20 \%)$ was observed with indole only. There was no forma- tion of the corresponding triindolylmethane with other indole derivatives. The formation of triindolylmethane may be considered to proceed through the successive formation of the expected diindolylmethane and indoleninium species. The structure of 6e was also confirmed further by the single crystal $\mathrm{X}$-ray analysis (figure 1$)^{12}$

The interaction of the compound 3d in DMSO $(40 \mu \mathrm{M})$, was investigated by titrating with CTDNA in Tris buffer. As shown in figure 2, on addition of $7 \mu \mathrm{M}$ of DNA, the absorption band centered at $489 \mathrm{~nm}$ is disappeared and a new band at higher energy was observed at $447 \mathrm{~nm}$. The binding constant was deduced to be $1.4 \times 10^{5} \mathrm{M}^{-1}$ using nonlinear least-squares treatment of UV/Vis titrations. As can be expected from UV/vis data (figure 2), colour change occurs from orange to pale yellow colour of the dye $3 \mathbf{d}$ by the addition of $10 \mu \mathrm{M}$ of DNA (figure $3)$. Further addition of DNA $(100 \mu \mathrm{M})$ caused the colour change of the solution from pale yellow to light reddish brown (figure 3) while in the UVVisible spectrum (figure 2), the band at $447 \mathrm{~nm}$ dis- 
appears and a new band appeares at $491 \mathrm{~nm}$. This optical response may be due to the non-covalent interactions between DNA and di(diindolylmethyl) carbazole moiety. We have also carried out ${ }^{1} \mathrm{H}$ and

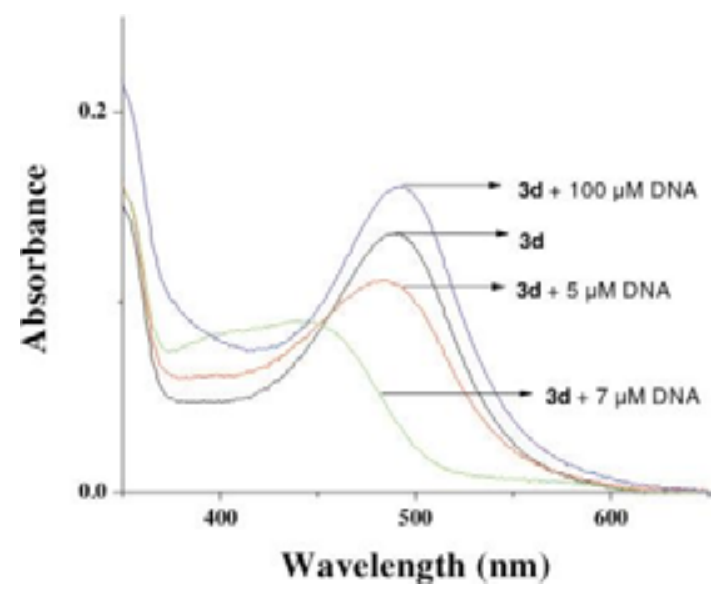

Figure 2. Family of UV-Vis spectra taken in the course of the titration of DMSO solution of 3d $(40 \mu \mathrm{M})$ with CT-DNA in Tris buffer.

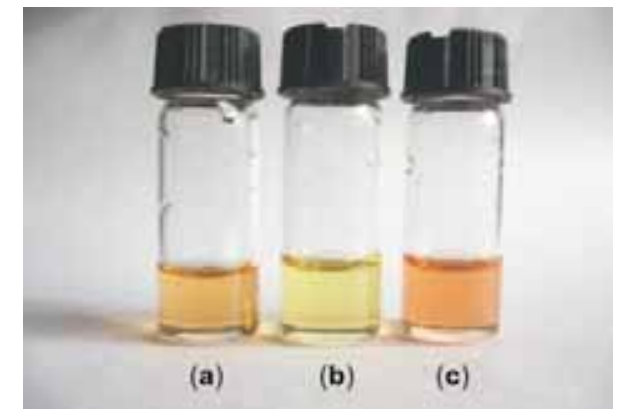

Figure 3. Colour changes upon the addition of CTDNA to the DMSO solution of 3d $(50 \mu \mathrm{M})$ from left to right: (a) 3d, (b) 3d $+10 \mu \mathrm{M}$ of DNA, (c) 3d $+100 \mu \mathrm{M}$ of DNA.

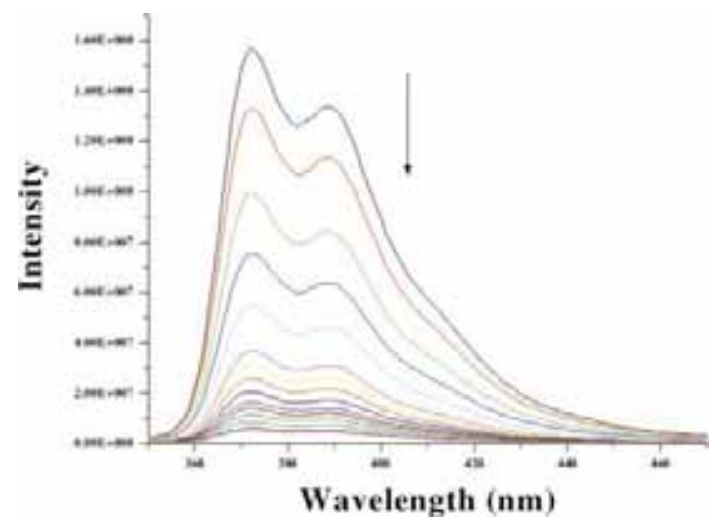

Figure 4. Fluoroscent titration curves for 3d upon incremental additions of CT-DNA. DNA concentrations: 0, $2.5,5,7,9.5,15,20,25,30,40,50 \mu \mathrm{M}$.
${ }^{31} \mathrm{P}$ NMR titrations of $3 \mathbf{i}$ with DNA. All the protons of di(diindolylmethyl)carbazole moiety were moving to the upfield which indicates that the absence of hydrogen bonding and the presence of non-covalent interactions. In ${ }^{31} \mathrm{P}$ the singlet was splitted into four new peaks (see supplementary information).

Other di(diindolylmethyl)carbazole derivatives were also exhibiting similar behaviour like 3d. On the addition of DNA aliquots to $3 \mathrm{i}(40 \mu \mathrm{M})$, the peak at $514 \mathrm{~nm}$ disappears and a new peak at $407 \mathrm{~nm}$ appears in the UV-Vis spectrum which results the colour change of the dye from pink to pale yellow (see supplementary information). Further addition of DNA $(100 \mu \mathrm{M})$, the peak at $407 \mathrm{~nm}$ disappears and a new peak at $512 \mathrm{~nm}$ evolved (see supplementary information). Again the colour changes from pale yellow to intensive pink colour (see supplementary information). The colour of $\mathbf{3 p}$ changes from violet to pale yellow corresponding to the disappearance of the peak at $551 \mathrm{~nm}$ and the appearance of a new peak at $440 \mathrm{~nm}$ upon the addition of DNA aliquots. Again the colour changes from pale yellow to violet after addition of DNA $(100 \mu \mathrm{M})$ and the peak at $440 \mathrm{~nm}$ disappeared and a new peak at $548 \mathrm{~nm}$ appeared (see supplementary information).

But di[di(1-methylindolylmethyl)]carbazole derivatives did not give any colour change after the addition of excess of DNA also. Absorbance of the peak at $498 \mathrm{~nm}$ decreased but there was no new peak was observed (see supplementary information). This clearly indicates that the $\mathrm{NH}$ protons were playing a major role for the optical response of the other di(diindolylmethyl)carbazoles.

All di(diindolylmethyl)carbazole derivatives are fluorescent. The fluorescent intensity of all derivatives was going to quench after the addition of DNA. As shown in figure 4, the intensity of characteristic emission maximum at $372 \mathrm{~nm}$ and $389 \mathrm{~nm}$ gradually decreases upon the incremental addition of DNA upon exciting at $280 \mathrm{~nm}$. Di(diindolylmethyl) pyrroles could not give any colour change even after adding the excess of DNA also.

\section{Conclusions}

In conclusion, we have synthesized di(diindolylmethyl)carbazoles and pyrroles by employing a new catalyst $\mathrm{PPh}_{3} . \mathrm{CF}_{3} \mathrm{SO}_{3} \mathrm{H}$ and also demonstrated the utility of the di(diindolylmethyl)carbazole derivatives for the colourimetric and fluorometric detection of DNA. 


\section{Acknowledgements}

We gratefully acknowledge the Council of Scientific and Industrial Research (CSIR) for financial assistance and Department of Science and Technology (DST) for providing single crystal X-ray difractometer facility in our school. R M thanks CSIR for Fellowship.

\section{References}

1. (a) Wang J 2000 Nucleic Acids Res. 28 3011; (b) Niemeyer C M, Blohm D, 1999 Angew. Chem., Int. Ed. 382865

2. (a) Pu L. 2004 Chem. Rev. 104 1687; (b) Valeur B 2002 Molecular fluorescence: principles and applications (Weinheim: Wiley-VCH)

3. Prentø P 2001 Biotech. Histochem. 76137

4. Cantor C R and Schimmel P R 1980 In Biophysical chemistry (San Francisco: W.H. Freeman and Co) Part II, p. 392

5. Granzhan A, Ihmels $\mathrm{H}$ and Viola G $2007 \mathrm{~J}$. Am. Chem. Soc. 1291254

6. Knölker H J and Reddy K R 2002 Chem. Rev. 1024303

7. (a) Sundberg R J 1970 The chemistry of indoles (New York: Academic Press; (b) Katritzky A R and Taylor R 1990 Adv. Heterocycl. Chem. 4787142
8. Jones R A 1992 Pyrroles, Part II (New York: Wiley)

9. (a) Porter J K, Bacon C W, Robins J D, Himmelsbach D S and Higman H C 1977 J. Agric. Food Chem. 25 88; (b) Osawa $\mathrm{T}$ and Namiki M 1983 Tetrahedron Lett. 24 4719; (c) Fahy E, Potts B C M, Faulkner D J and Smith K 1991 J. Nat. Prod. 54 564; (d) Chakrabarty M, Basak R and Harigaya Y 2001 Heterocycles 552431

10. (a) Ramesh C, Banerjee J, Pal R and Das B $2003 A d v$. Synth. Catal. 345 557; (b) Bandgar B P and Shaikh K A 2003 Tetrahedron Lett. 44 1959; (c) Koshima H and Matsusaka W 2002 J. Heterocycl. Chem. 39 1089; (d) Chen D P, Yu L B and Wang P G 1996 Tetrahedron Lett. 374467 (e) Nagarajan R and Perumal P T 2002 Tetrahedron 58 1229; (f) Mi X L, Luo S Z, He J Q and Chen J P 2004 Tetrahedron Lett. 45 4567; (g) Wang L, Han J, Tian H, Sheng J, Fan Z and Tang X 2005 Synlett. 337 (h) Yadav J S, Reddy B V S and Sunitha S $2003 A d v$. Synth.Catal. 349; (i) Gu D G, Ji S J, Jiang Z Q, Zhou M F and Loh T P 2005 Synlet. 95911

11. Chakrabarty M, Ghosh N, Ramkrishna B and Harigaya Y 2002 Tetrahedron Lett. $\mathbf{4 3} 4075$

12. The CCDC deposition number of compound $6 \mathrm{e}$ is 653448; formula: $\mathrm{C}_{71} \mathrm{H}_{61} \mathrm{Cl}_{2} \mathrm{~N}_{5} \mathrm{O}_{4}$; unit cell parameters: a 16.6198(10), b 21.5543(13), c 17.8697(10), $\beta$ 110.6790(10), space group P2(1)/n 